\title{
Arm op het Veen
}

et was half een grapje. Toen mij als burgemeester van de Drentse gemeente Aa en Hunze in een interview werd gevraagd wat de volgende stap in mijn loopbaan zou zijn, zei ik: 'Ik word in ieder geval niet de burgemeester van Wassenaar.' Opgegroeid in een Haagse volkswijk op een klein flatje was 'Wassenaar' een andere wereld. Een wereld waarin je wel eens naar een restaurant ging, kleren niet eindeloos werden versteld en niet werd gevoetbald met slappe plastic ballen van hooguit twee gulden.

Deze relatief arme start stuurde mijn loopbaan. De volgende stap in mijn carrière zou passen in het rijtje van eerdere werkplaatsen als Delfzijl, Pekela, Veendam en de Veenkoloniën. Ik werd burgemeester van Emmen. Dat was dus een logische stap (grappig detail: ik werd in Gieten opgevolgd door de burgemeester van...

Wassenaar).

Het zijn plaatsen en regio's die om het op zijn Drents te zeggen niet tot de Goudkust van Nederland behoren. Op het eerste oog straalt ook in Noord-Oost Nederland de welvaart je tegemoet. Maar een blik achter de deur laat zien dat armoede in al zijn verschijningsvormen hier relatief vaak voorkomt. Ook de concentratie van armoede onder jongvolwassenen is zorgelijk. Uit de eerste verkenningen blijkt dat ouders van arme kinderen relatief zelf ook arm zijn. Dat lijkt logisch, maar de verklaring is complexer. Ook in Emmen zit meer dan tien procent van de mensen onder de lage-inkomensgrens.

\section{Alliantie}

Als burgemeester werd ik al snel benaderd met de vraag of ik wat wilde betekenen voor de Alliantie van Kracht. Deze Alliantie van Kracht zou moeten gaan om nieuwe vormen van de aanpak van armoede. De gedachtegang was om een soort Bondgenootschap te sluiten met allerlei partijen in de Veenkoloniën die aanlopen tegen armoedekwesties: bijvoorbeeld gemeenten, provincies, de ggz, welzijnsinstellingen, woningbouwcorporaties en de GGD. Voor de vorm werd gekeken naar het 'Bondgenootschap voor een geletterd Drenthe': ruim zestig partijen die hebben verklaard iets te willen aan doen aan het bestrijden en voorkomen van laaggeletterdheid.

In de Alliantie van Kracht verbinden partijen zich in de strijd tegen armoede. We organiseren onderzoek, leerkringen en ontmoetingen om meer grip te krijgen op dit ingrijpende probleem. Een interessante club van betrokken experts en ervaringsdeskundigen heeft aangegeven hier wat in te willen betekenen.

De eerste indrukken zijn positief. Na het flitsende openingscongres zijn de leerkringen van start gegaan. Ook is de aanzet gegeven tot een meerjarig onderzoek naar de mechanismen die ervoor zorgen dat de armoede in de Veenkoloniën een intergenerationeel karakter heeft. We weten wel zo'n beetje waar armoede zich voordoet. Maar hoe manifesteert deze zich? En hoe komt dat er een schijnbare 'erfelijke' component in zit, waardoor families generatie op generatie in de armoede zitten? En is er vanuit die ingrijpende analyse ook een richting te vinden om de armoede structureel te verbeteren?

Kortom, werk aan de winkel voor een Emmer burgemeester, die het grootste deel van zijn werkzame leven in de Veenkoloniën aan de slag is. Onze mensen op het Veen verdienen het.

\section{Eric van Oosterhout,}

Burgemeester Emmen

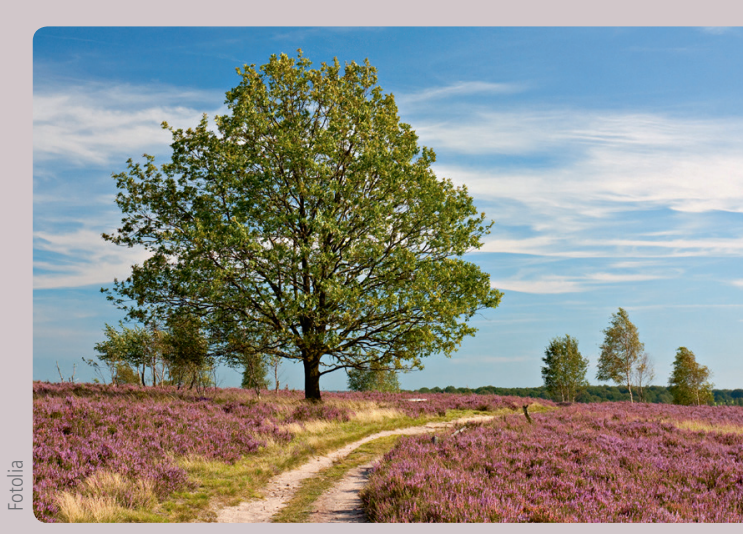

Drenthe is meer

dan heide. Achter de

voordeur is er veel

armoede. 